\section{Gene patents do not hinder academic research}

To the Editor: Last month's Nature Methods Editorial ('Genes-to have and to hold') 1 perpetuates mistaken assumptions about the operation of the patent system and stirs up unfounded fears about the impact of patents on genetic research. The editors concede that there has not been a single lawsuit against academic researchers for the infringement of a gene patent, and they

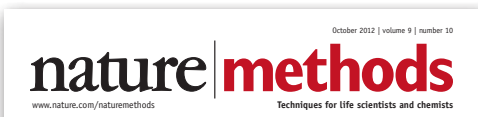
produce no evidence that such patents have otherwise acted as a research impediment during the past 30 years. Nonetheless, the Editorial paints an unrealistic and alarmist picture in which those who conduct basic academic research should be worried about legal liability for patent infringement on the basis of vague notions of "legal gray zones" in which corporate patent owners "have the right to prevent anyone from studying a gene."

The number of reported patent lawsuits involving gene patents is practically nonexistent. A 2008 study identified only six instances in which such patents had been briefly asserted against clinical diagnostic testing, and none against basic research ${ }^{2}$. This finding is consistent with earlier reports by the US National Research Council ${ }^{3}$ and Walsh et al. ${ }^{4}$, which found little empirical evidence to support the notion that patents created obstacles to biomedical research. A Canadian survey found that although genomics researchers expressed much concern about patents, there is little evidence to show that the progress of research is in fact being seriously hindered ${ }^{5}$. These and other empirical survey findings were recently corroborated by detailed legal analyses that explain the limitations of these patents and their narrow reach into emerging genetic technologies ${ }^{6,7}$.

Throughout the $1990 \mathrm{~s}$, it was feared that 'thickets' of gene patents would block the impending commercialization of DNA microarray technology. These fears completely failed to materialize-yet, 20 years later, the exact same hypothetical arguments are being resurrected in the context of whole-genome sequencing.
Gene patents, like other patents, are critical to the development of basic research inventions into cures and therapies for patients as well as drought- and pest-resistant crops and renewable sources of energy.

Encouraging the notion that scientists today routinely incur legal liability whenever they conduct genetic research may inflame public debate over 'gene patents', but it has nothing to do with a realistic appraisal of the role of patents in academic research. The likelihood that a researcher will infringe a technology patent by using a smartphone is much higher than the risk of infringing a 'gene patent' by doing benchwork.

\section{COMPETING FINANCIAL INTERESTS}

The author declares competing financial interests: details are available at http:// www.nature.com/doifinder/10.1038/nmeth.2245.

\section{Jim Greenwood}

Biotechnology Industry Organization, Washington, DC, USA. e-mail:mcgirt@bio.org

1. Anonymous. Nat. Methods 9, 931 (2012).

2. Holman, C.M. Science 322, 198-199 (2008).

3. National Research Council. Reaping the benefits of genomic and proteomic research: intellectual property rights, innovation, and public health (National Academies, Washington, DC, 2006).

4. Walsh, J.P., Cho, C. \& Cohen, W.M. Patents, material transfers and access to research inputs in biomedical research. <http://www2.druid.dk/conferences/ viewpaper. php?id $=776 \& \mathrm{cf}=8>(2005)$

5. Murdoch, C.J. \& Caulfield, T. Genome Med. 1, 22 (2009).

6. Holman, C.M. Will gene patents derail the next-generation of genetic technologies?: a reassessment of the evidence suggests not. UMKC Law Rev. 80, 563-606 (2012).

7. Price, W.N. II Unblocked future: why gene patents won't hinder whole genome sequencing and personalized medicine. Cardozo Law Rev. 33, 16011631 (2012).

Nature Methods replies: We thank the authors for their opinion $^{1}$, and we want to emphasize that no basic researcher has faced legal action due to gene patent infringement to date. Nonetheless, we stand by our original statements that such legal action is not inconceivable in the future and that researchers have voiced frustration with the current practice of gene patenting. A study by Gold and Carbone ${ }^{2}$ discusses the effect of the $B R C A 1$ and $B R C A 2$ patents on the scientific community (readers can find a link to this study on the Nature Methods blog, Methagora). We also stand by our statement that gene patents may hinder the rapid advancement of personalized medicine because companies seem reluctant to invest in diagnostic kits involving genes whose patents are held by other companies, even if the technology used should not infringe this patent.

\footnotetext{
1. Greenwood, J. Nat. Methods 9, 1039 (2012).

2. Gold, R.E. \& Carbone, J. Genet. Med. 12, S39-S70 (2010).
} 